\title{
Virtual Knowledge Sharing in Crowdsourcing: Measurement Dilemmas
}

\section{Regina Lenart-Gansiniec ${ }^{1}$}

\begin{abstract}
One relatively new area of contemporary science research on management is crowdsourcing and virtual knowledge sharing occurring within it. It is defined as the dissemination of knowledge by a virtual community, informing others, making it public, expecting that others will comment on this knowledge, expand and complete it. Such a sharing of knowledge is particularly important for co-creating, participating, or acquiring innovative ideas by an organization. However, despite its positive impact on the organization, it has not been the subject of comprehensive research so far. This article presents the existing output in the scope of the ways of measuring community knowledge sharing within crowdsourcing. In this elaboration, explanations as to why it is worth studying virtual knowledge sharing may be found.
\end{abstract}

Keywords: virtual knowledge sharing; virtual community; measurement.

\section{INTRODUCTION}

In the literature on management it has been pointed out that knowledge is a resource, which may be the source of above average economic benefits, economic rent, and it also enables solutions to organizational problems (Bollinger \& Smith, 2001, pp. 8-18; Krupski, Niemczyk \& Stańczyk-Hugiet, 2009, p. 80). In order for organizations to tap into this potential, treating knowledge in an appropriate way and unconventional solutions are important (Kowalczyk \& Nogalski, 2007, p. 33). Knowledge should be subject to constant identification, measurement, acquiring, development, use, and protection. It gains in strategic importance at the moment of its use (Yang, 2007) and transfer or exchange.

Knowledge sharing is considered a critical condition for every organization, a factor of creating new knowledge, creating innovations (Liao,

1 Regina Lenart-Gansiniec, Ph.D., Jagiellonian University, ul. Łojasiewicza 4, 30-348 Kraków, Poland, e-mail: regina. lenart-gansiniec@uj.edu.pl. 
2006), improving individual and organizational efficiency (Quigley, Tesluk, Locke \& Bartol, 2007), making changes and adapting to the requirements of the environment (Sharratt \& Usoro, 2003) as well as achieving a durable competitive advantage. The assumption underlying knowledge sharing is that an essential condition is diversification of the participants in the sharing process (Nonaka \& Takeuchi, 1995; Wenger, 1998). From this perspective, crowdsourcing gains in importance, particularly taking into account its potential related to its ability to simultaneously acquire human knowledge from many sources, which are located outside the organization (Howe, 2008; Brabham, 2008; Lodge \& Wegrich, 2014). The basis is the co-creation of knowledge according to the rules of voluntary collaboration of many Internet users (Chiu et al., 2006; Sloane, 2011).

An organization should above all reach for resources which are located beyond its borders. Knowledge may be acquired by collaboration with other entities, but also from communities of practitioners. Along with the growth of the importance of information and communication technologies, it has been pointed out more and more often that organizations may reach for information, which is found in virtual communities. They not only constitute the knowledge basis, but they also want to co-participate in organization creation. Knowledge sharing is for them a way of life (Din \& Haron, 2012). This process is defined as the dissemination of knowledge by the virtual community, informing others, making it public, expecting that others will comment on this knowledge, expand and complete it. The basis is the cocreating of knowledge by means of voluntary collaboration of many Internet users (Sloane, 2011). In the literature, the importance of trust towards the organization and other members of the virtual community gathered around a crowdsourcing platform, the level and way of participation, the ability and will to share knowledge, a feeling of a virtual community, and congruence value, have all been emphasized.

Although, crowdsourcing is an idea based on the crowd's sharing of its knowledge, ideas, and projects and acquiring this knowledge by the organization - the existing elaborations, mainly theoretical, have focused above all on the crowd's motivation and the factors impacting virtual knowledge sharing. The issue of measuring virtual knowledge sharing in the context of crowdsourcing is, however, omitted (Kosonen et al., 2013). The goal of this article is to identify the ways or methods of measuring the community's knowledge sharing in crowdsourcing. Based on this, and taking into consideration the related scarcity, an original measuring method has been proposed. In the elaboration it is also possible to find explanations as to why it is worth studying virtual knowledge sharing. The article is based on the results of a review of Polish and foreign literature from the years 2006-2017. 
The article is composed of three parts. The first part contains definitions of the virtual community, knowledge sharing, and virtual knowledge sharing. In the second part the notion and essence of crowdsourcing are included. The last and third part focuses on a review of the ways of measuring virtual knowledge sharing.

\section{LITERATURE REVIEW}

\section{Virtual communities}

Virtual communities are expressed as an aggregation of persons or business partners that collaborate with one another, which is based on common goals, interests, needs, or other activity. The basis is constituted by a will to be a part of a community. Other definitions express them as self-defining networks of interactive communication, organized around each interest or aims (Pańkowska, 2007). They communicate regularly with each other by means of electronic media and they have common interests (Romm, Pliskin \& Clarke, 1997). These communities are characterized by the following conditions: repeated involvement, active participation, strong emotional bonds, and common actions, access to common resources and defining the rules of access to them, mutuality of information, support, common context of social convention, language, and protocol, a will to interact in order to satisfy one's needs, common interests, norms which guide the relationships, and computer systems which assure support and integrity among members.

In addition they are characterized by the fact that they are not geographically or territorially limited, communication between them does not have to take place in real time, nonverbal communication is replaced by the so-called emoticons, and interactions between the members are very often anonymous. Moreover, as Wadhwa \& Kotha (1999) point out, virtual communities form around common needs, whereas the members are people who are usually in a better financial situation, better educated, and have constant access to the Internet. The fact of being a member is intended, purposeful, and rational and it enables the creation of social relations ( $L$, Zhao \& Wang, 2010), and intense and strong emotional bonds (Whittaker, Issacs \& O'Day, 1997). Each virtual community has its own culture and expectations, norms, and values, conditions of access to resources, information, assistance, and services to its members. Their interactions are based on an ongoing, multilateral exchange, which takes place through online communication (Murphy, 1997). 


\section{Knowledge sharing}

Knowledge sharing is one of the key elements of the whole process of knowledge management and a critical stage of acquiring knowledge. It is defined as a process of disseminating knowledge within a specific group of employees (Van den Hooff \& De Ridder, 2004), focused on exploiting the existing knowledge and identifying the existing and accessible knowledge in order to pass (transfer) and use to achieve a better, faster, or cheaper execution of a given task than would happen without sharing knowledge. It is a diversified action, based on exchange relations, which contain expectations for obtaining financial and non-financial benefits in the future for people participating in this process (Reychav \& Weisberg, 2009). It mainly consists of providing information connected with a task or know-how (Wang, Noe, 2010). Knowledge sharing includes the process of communication, in which two or more parties take part in providing and acquiring knowledge (Usoro, Sharratt, Tsui \& Shekhara, 2007). It occurs when people mutually share overt or hidden knowledge in order to create new knowledge (Van den Hooff \& de Leeuw van Weenen, 2004).

Knowledge sharing is considered a critical condition for every organization (Majchrzak \& Malhotra, 2013), a factor of creating new knowledge, creating innovation (Liao, 2006), improving individual and organizational efficiency (Verburg \& Andriessen, 2011), making changes and adapting to the requirements of the surroundings (Sharratt \& Usoro, 2003) and obtaining a durable competitive advantage (Van den Hooff \& De Ridder, 2004). In order to reach for these possibilities it is required that the members of an organization share their knowledge (Nissen, 2007). At the basis of knowledge sharing is a process, which preceded the creation of organizational knowledge, an assumption that the necessary condition is the diversity of the participants of this exchange process (Nonaka \& Takeuchi, 1995; Wenger, 1998). In addition, a surplus and diversity of knowledge is the source of creating something new.

\section{Virtual knowledge sharing}

As has already been mentioned, knowledge sharing is defined in the literature as a process of disseminating knowledge within a specific group. However, beside this concept such concepts as "virtual knowledge sharing" and "community knowledge sharing" may be found. Importantly, it should be emphasized that these concepts are not identical. Virtual knowledge sharing is in short sharing knowledge about a given subject by virtual communities. However, a virtual community is defined herein as an aggregation of individuals or business partners who interact around a shared interest, 
where the interaction is at least partially supported and/or mediated by technology and guided by some protocols or norms (Lee et al., 2003; Preece, 2000). In turn, community knowledge sharing is sharing knowledge within communities of practices to provide a platform for employees to share professional knowledge and gain knowledge for professional development. It is a group of people who share common interests, goals, or practices and share information and knowledge (Liu et al., 2011).

Virtual knowledge sharing refers to three aspects: (1) interactions between people in a knowledge network; (2) on-line environments; (3) knowledge sharing in an on-line process. It is defined as the dissemination of knowledge by the virtual community, informing others, making it public, expecting that others will comment on this knowledge, expand and complete it. It refers to knowledge sharing using IT technology (Li, Downey \& Wentling, 2008). The basis is co-creating knowledge on the basis of collaboration of many Internet users (Sloane, 2011) and technologies, which enable delegating and reacting (Wasko \& Faraj, 2005). In the literature, the importance of engaging in social interactions, building of public welfare (Wasko \& Faraj, 2005), trust towards the organization and other members of the virtual community gathered around an Internet platform, the level and way of participating, an ability and willingness to share knowledge, a feeling of a virtual community, and congruence value, are all emphasized. Despite the fact that virtual knowledge sharing is a specific case of knowledge sharing those elements, which contribute to knowledge sharing becoming virtual knowledge sharing are worth pointing out (Table 1).

Table 1. Comparison of knowledge sharing and virtual knowledge sharing

\begin{tabular}{|c|c|c|}
\hline Criterion & Knowledge sharing & Virtual knowledge sharing \\
\hline Synonyms & Knowledge sharing & Online knowledge sharing, virtual knowledge sharing \\
\hline Processes & $\begin{array}{l}\text { Externalization (explaining, cod- } \\
\text { ing, transfer from hidden to overt } \\
\text { knowledge), internalization (seek- } \\
\text { ing a goal in knowledge acquiring, } \\
\text { transfer from overt to hidden } \\
\text { knowledge) }\end{array}$ & $\begin{array}{l}\text { Externalization (explaining, coding, transfer from hid- } \\
\text { den to overt knowledge), internalization (seeking a } \\
\text { goal in knowledge acquiring, transfer from overt to } \\
\text { hidden knowledge) }\end{array}$ \\
\hline $\begin{array}{l}\text { Knowledge } \\
\text { type }\end{array}$ & Overt and silent knowledge & Overt and silent knowledge \\
\hline Way & $\begin{array}{l}\text { Formal and informal communica- } \\
\text { tion methods }\end{array}$ & $\begin{array}{l}\text { Social media, discussion forums, e-mails, blogs, elec- } \\
\text { tronic bulletins, crowdsourcing platforms }\end{array}$ \\
\hline Stages & $\begin{array}{l}\text { Transferring acquired, processed, } \\
\text { and gathered knowledge to lower } \\
\text { organization levels }\end{array}$ & $\begin{array}{l}\text { Necessity of having Internet access, creating an ac- } \\
\text { count and logging onto a special platform, entries on } \\
\text { a website, starting a discussion with other members } \\
\text { of the virtual community, coordination }\end{array}$ \\
\hline
\end{tabular}




\begin{tabular}{|c|c|c|}
\hline Criterion & Knowledge sharing & Virtual knowledge sharing \\
\hline Goals & $\begin{array}{l}\text { Gaining experience, joining in } \\
\text { creating of new knowledge, im- } \\
\text { provement of organizational ef- } \\
\text { fectiveness }\end{array}$ & $\begin{array}{l}\text { Strengthening of the professional reputation of the } \\
\text { virtual community members, altruistic, conform- } \\
\text { ist, receiving a financial award, gaining prestige, will } \\
\text { to be seen by others, acquiring of new knowledge } \\
\text { (organization) }\end{array}$ \\
\hline Actions & $\begin{array}{l}\text { Individuals adapt their beliefs, } \\
\text { actions through more or less in- } \\
\text { tensive interactions, members of } \\
\text { the organization share ideas, sug- } \\
\text { gestions, and expert knowledge } \\
\text { among themselves }\end{array}$ & $\begin{array}{l}\text { Appearance of a reply to an online request for assis- } \\
\text { tance, problem solving }\end{array}$ \\
\hline Relations & $\begin{array}{l}\text { People-people relations, level of } \\
\text { individual knowledge of the em- } \\
\text { ployees, who possess it, and the } \\
\text { organization level }\end{array}$ & $\begin{array}{l}\text { Relations with other members of the virtual commu- } \\
\text { nity }\end{array}$ \\
\hline
\end{tabular}

It is pointed out in the literature that people in virtual communities do almost everything, which they do in real life, only that they leave their bodies outside reality (De Kerckhove, 2001). Nonetheless, some differences appear between knowledge sharing and virtual knowledge sharing, which were grouped according to: process course, benefits, technologies, and motivation.

\section{Environment}

In virtual knowledge sharing it is important to create an environment of sharing knowledge, coordination of virtual community's actions, gaining trust and satisfaction of virtual community members, which may next increase their efficiency. The Internet is of special importance. It supports knowledge sharing amongst the organization's members, and it contributes to disseminating and sharing information and knowledge (Van Doodewaard, 2006). It enables the levelling of barriers and particularly those connected with the distance between employees or teams and locating the possessors of knowledge and potential recipients. The latter entails, therefore, significant challenges, even those resulting from a lack of possibility to use nonverbal communication.

\section{Benefits}

Sharing knowledge is considered the key factor of a company's success (Davenport \& Prusak, 1998). It may contribute to increasing the efficiency of a given group of employees, coordination of other processes in a given organization (Alavi \& Leidner, 1999; Salisbury, 2003), competitive advantage, cost reduction, accelerating realization of new product development projects, innovative potential, sales and income growth from new products and 
services (Arthur \& Huntley, 2005; Collins \& Smith, 2006; Cummings, 2004; Hansen, 2002; Lin, 2007; Mesmer-Magnus \& DeChurch, 2009), changing and developing organizational competences, collaboration, which may give a basis for creating innovative solutions. It is imperative in transforming individual knowledge into organizational knowledge, as it also stimulates the creation of new ideas, and creates new products (Hong, Doll, Revilla \& Nahm, 2011). Moreover, it constitutes an element of many management concepts, among others: team work management, knowledge management, comprehensive quality management, an organizational learning (Rudawska, 2013). Virtual knowledge sharing can increase the creativity and quality of communication (Charband \& Navimipour, 2016), employee productivity and efficiency, creativity, quality of communication, increase the possibility of achieving success by the organization, and learning optimising.

\section{Motivation}

In knowledge sharing, motivation along with experience, education, and perspectives constitutes the "critical step" (Nonaka \& Takeuchi, 2000). The will and willingness of people, who possess and develop their knowledge for knowledge sharing alone means that it is possible to increase the value of organizational knowledge (Ipe, 2003). In knowledge sharing, the motives may be as follows: integration of employees with the organization's goals, connecting the individual perspective with the organizational one, orientation towards the future, readiness to give up existing knowledge, experiences, and skills, lack of fear of novelty, willingness to search for new solutions, readiness to imitate the ideas of others, clear and transparent criteria of awarding, a feeling of participating in the organization's development (Kożuch \& Lenart-Gansiniec, 2016). In virtual knowledge sharing a large significance of motivational factors is emphasized - it is indicated that people do not share knowledge only because they have access to the intranet. The most important ones include, among others: possibility of creating new products (Fuchs \& Schreier, 2011), innovation (Füller \& Matzler, 2007; Sawhney et al., 2005), interacting with other members of the virtual community (Faraj et al., 2011; Von Hippel et al., 2011; Sawhney et al., 2005), testing one's skills, facing a difficult task and a willingness to learn something new, developing knowledge (Sloane, 2011), which is important for the organization's growth (Nooteboom, 2000). Another reason is also knowledge sharing. Despite the fact that the last motive is indicated as important in crowdsourcing, it is omitted in the subject literature (Zheng et al., 2011). 


\section{Crowdsourcing}

The notion of crowdsourcing appeared for the first time in the subject literature in 2006, and is attributed to Howe. He defined crowdsourcing as an "act of a company or institution taking a function once performed by employees and outsourcing it to an undefined (and generally large) network of people in the form of an open call. This can take the form of peer-production (when the job is performed collaboratively), but is also often undertaken by sole individuals" (Howe, 2006). With time, the author expanded this definition by using the rules of an open source, not only in the scope of programming, but also delegating tasks to the crowd, adapting the crowd's talent and knowledge to the organization's needs.

It should also be mentioned that crowdsourcing-taking into consideration its versatility - is used by researchers to explain various phenomena, including many perspectives (Table 2).

Table 2. Crowdsourcing research perspective

\begin{tabular}{|c|c|c|}
\hline Author & Perspective & Problematic aspects discussed \\
\hline $\begin{array}{l}\text { Afuah \& Tucci (2012); Pénin \& } \\
\text { Burger-Helmchen (2011) }\end{array}$ & $\begin{array}{l}\text { Behavioral and evolutionary the- } \\
\text { ories of the company: }\end{array}$ & Problem solving \\
\hline Afuah \& Tucci (2012) & Organizational ambidexterity & Problem solving \\
\hline $\begin{array}{l}\text { Horton \& Chilton (2010); Schenk } \\
\text { \& Guittard (2011) }\end{array}$ & Agency theory & Problem solving \\
\hline $\begin{array}{l}\text { DiPalantino \& Vojnovic (2009); } \\
\text { Archak \& Sundararajan (2009) }\end{array}$ & Auction theory & Problem solving \\
\hline $\begin{array}{l}\text { Jeppesen \& Lakhani (2010) } \\
\text { (2010); Pénin \& Burger-Helm- } \\
\text { chen (2011) }\end{array}$ & Knowledge management & $\begin{array}{l}\text { Generating ideas, creating inno- } \\
\text { vations }\end{array}$ \\
\hline $\begin{array}{l}\text { Afuah \& Tucci (2012); Pénin \& } \\
\text { Burger-Helmchen (2011) }\end{array}$ & Transaction cost theory & $\begin{array}{l}\text { Generating ideas, creating inno- } \\
\text { vations }\end{array}$ \\
\hline Lane (2010) & Value chain & $\begin{array}{l}\text { Generating ideas, creating inno- } \\
\text { vations }\end{array}$ \\
\hline Trompette (2008) & Innovation theory & $\begin{array}{l}\text { Generating ideas, creating inno- } \\
\text { vations }\end{array}$ \\
\hline Bayus (2010) & Motivation support theory & Motivation in crowdsourcing \\
\hline Bayus (2010) & Cognitive evaluation theory & Motivation in crowdsourcing \\
\hline Leimeister et al. (2009) & MIAB Mode & Motivation in crowdsourcing \\
\hline $\begin{array}{l}\text { Bayus (2010); Schlagwein \& } \\
\text { Bjørn-Andersen (2014) }\end{array}$ & Organizational learning & $\begin{array}{l}\text { Acquiring knowledge from the } \\
\text { crowd }\end{array}$ \\
\hline Mazzola \& Distefano (2010) & Strategic management & Decision making \\
\hline
\end{tabular}

Source: authors' work based on Majchrzak \& Malhotra (2013).

Crowdsourcing is deemed an expression of open innovations (Sloane, 2011). What links crowdsourcing and open innovations is reaching for knowledge, ideas, opinions of the virtual community (Pichlak, 2012). 
Crowdsourcing also contributes to solving problems, creating innovations, optimising costs of the organization's activity, or it is formulated as a marketing and customer collaboration tool. Crowdsourcing may constitute a source of competitive advantage (Leimeister \& Zogaj, 2013). The possibilities of making use of crowdsourcing to improve business processes have been emphasized (Brabham, 2008). Taking into consideration its potential, it enables access to the resources of knowledge and creativity, and it facilitates acquiring new contents and data (Kowalska, 2015). However, these problematic aspects have so far been identified only to a small extent.

\section{Dimensions of crowdsourcing}

Crowdsourcing is a multilevel term. Beside the level of the organization in the process the issue of the crowd appears. It is deemed in the literature as one of the sine qua non conditions of crowdsourcing (Surowiecki, 2004).

Most authors agree that the principal substance of crowdsourcing is the crowd's wisdom (Surowiecki, 2004). The crowd in crowdsourcing is not an unorganized, chaotic group, but it is rather a collectivity which expresses the will to react and be involved. It becomes a specific virtual community that is connected by interactions, relations, and common knowledge (Rheingold, 1993). It constitutes a confirmation that in crowdsourcing the group may achieve and work out more benefits than any expert. Its remit is performing tasks, solving problems, or taking on any type of activity (Basto, Flavin \& Patino, 2010). By the same token, the organization's motivation to make use of the crowd's wisdom is important. Many authors emphasize the necessity of remuneration for the crowd for the tasks performed (Vukovic, Mariana \& Laredo, 2009) and other motivators, e.g. social recognition, entertainment value, or money. Others point out that a task should be performed for free or for much less than the costs incurred by the firm (Kleeman, Voss \& Rieder, 2008). Some authors suggest that the best situation is one in which the award is not important and the motivation would be passion or participation in amusement (Stewart, Huerta \& Sader, 2009).

In the literature the initiator is called the "crowdsourcer", thus a person or an organization, which can mobilize a potentially useful crowd to take action (Franke et al., 2006). The initiator may be a private person, organization, institution, or local government unit. In most cases the initiators are commercial organizations. They can also be public organizations as well as private persons. This means that crowdsourcing is not only a business model for firms, but also a tool for solving problems for governmental or non-profit sectors (Brabham, 2008). In this connection, it may be ascertained that a crowdsourcer may be a given unit that possesses resources, an 
appropriate supply base (access to a platform, project promotion, payment of remuneration) to carry out an initiative.

The Internet and open collaboration with the crowd/virtual community gain importance here. The process may be directed outside, and then the crowd is asked to solve a given problem. The issue of a production model or partner production also appears which is based on collaboration and sharing resources and production results within it. Few authors express crowdsourcing as a process of open innovations, work organization (Whitla, 2009), or customer integration (Kleeman, Voss \& Rieder, 2008). In these approaches it is possible to see common points: online process, Internet, crowd participation, an open call. The last one may be directed at all interested parties, limited to a community, which possesses specializt knowledge or the call limited and controlled by the organization (Whitla, 2009).

\section{RESEARCH METHODS}

As previously mentioned, the primary aim of this article is to identify the ways or methods of measuring a community's knowledge sharing in crowdsourcing. Based on this, and taking into consideration the related scarcity, an original measuring method has been proposed. To this end, the methodology of a systematic literature review was applied. One of the main reasons for using this methodology is the need for a methodological regime, which is important if we are willing to fulfil the rule of continuity. As opposed to traditional literature reviews, a systematic literature review enables avoiding the dangers stemming out of subjectivism, a lack of a systematic approach, and prejudice. According to its methodology, the entire procedure includes three stages: (1) selecting databases and a collection of publications, (2) selection of the publications and development of a database, (3) bibliometric analysis, contents analysis, and verification of the usefulness of the obtained results for further research. The first stage constituted a choice of subject for research. This concerned specifying a collection of publications, which would be analysed. The basis at this point was selecting the databases. The analysis covered full text, large databases which include the majority of journals

dealing with strategic management i.e. Ebsco, Elsevier/Springer, Emerald, Proquest, Scopus, and ISI Web of Science. In order to establish the state of knowledge and existing findings, a review of the Polish databases BazEkon, and CEON was also carried out. They were selected owing to their integrity and completeness. The reason for using several databases simultaneously is down to their diverse range and the gathered resources and sources. The principal issue in defining the collection of publications is the choice 
of key words connected with the subject of research in order to identify potentially significant scientific articles from the point of view of the analysed problematic aspects. In each of the above-mentioned databases, key words were used which met the following criteria of inclusion: "crowdsourcing", "crowd sourcing" in the abstract, title, and key words. The base of publications obtained in such a way was further analysed and selected in the next stages. As a result of searching through the chosen databases, over 46,000 publications were selected from English language bases and 388 were selected from Polish language bases.

The second stage is based on imposing limitations and database selection according to the "snowball" procedure. Therefore, the following limitations were imposed on the identified articles: full text, reviewed publications and the area of management sciences. Publications related to IT, social, technical, mathematical, medical sciences, and humanities were excluded from the collection. Duplicating publications, books, dissertations, and book chapters were eliminated. Articles in their full version, published in journals and the so-called proceedings were included.

The third stage is the basis for identifying the areas for further research exploration, valuable from a cognitive point of view and important for the development of the theory of management. At this stage, the usefulness of the obtained elaborations for the realization of the research aims was verified. Those publications, which did not strictly concern crowdsourcing, but rather treated it as a secondary subject, were discarded. Only those publications, whose leading object of analyses had the term "crowdsourcing" in the title and key words, were deemed important from a research point of view. As a result, a literature base was obtained in the form of 54 publications selected from English language bases and 41 publications selected from Polish language bases. In the next stages, a total of 95 publications were further analysed using bibliometric techniques, including the frequency, number of publications, and citations. At this stage an analysis of the contents was also carried out, which enabled determining the findings of other researchers and their evaluation, and also organising the research findings. The results of this systematic literature review have been presented in the second part of this article.

\section{Measurement of virtual knowledge sharing in crowdsourcing}

Measuring virtual knowledge sharing may turn out to be a difficult process, for instance taking into account the intangibility of knowledge and, what is more, measuring knowledge requires the usage of many disciplines, among others psychology, sociology, or sciences dealing with organizational 
behaviors. Despite the fact that many researchers have made attempts to understand virtual knowledge sharing in the context of crowdsourcing some difficulties with direct measurement may be observed (Ko et al., 2005). The existing research may be brought down to two directions: (1) making use of psychological models of behavior, (2) models of knowledge sharing. In the case of models of behavior, the authors referred to the following theories (Table 3): Cognitive Evaluation Theory (Zhao \& Zhu, 2014), Self-Determination Theory (Cupido \& Ophoff, 2014), Theory of Reasoned Action (Fishbein \& Ajzen, 1975), Theory of Planned Behavior (Ajzen, 1991), Social Exchange Theory, Social Comparison Theory. Few developed original models of knowledge sharing, for example Knowledge Sharing Model by Ma and Yuen (2011). Many authors build on the proposal of Wasko and Faraj (2005), which expresses the model of knowledge sharing - referring to the theory of capital and the social cognitive theory. The notion of social cognitive theory was introduced by Hsu, Ju, Yen and Chang (2007), whereas the theory of social and personal investments was proposed by Chang and Chuang (2011). A compilation of the ways to measure virtual knowledge sharing was presented in Table 3.

Table 3. Ways of measuring virtual knowledge sharing

\begin{tabular}{lll}
\hline Author(s) & Way of measuring & Measurement metrics \\
\hline Chiu, Hsu \& Wang (2006) & $\begin{array}{l}\text { Cognitive evaluation } \\
\text { theory }\end{array}$ & $\begin{array}{l}\text { need for autonomy, competence and social relation- } \\
\text { ship, social context of events (e.g. feedback, commu- } \\
\text { nication, awards), financial awards }\end{array}$ \\
Yoon \& Rolland (2012) & $\begin{array}{l}\text { Self determination } \\
\text { theory }\end{array}$ & $\begin{array}{l}\text { internal autonomous motivation, controlled, and ex- } \\
\text { ternal, giving of satisfaction and possibility of freedom } \\
\text { of behavior. Knowledge sharing is motivation per se } \\
\text { for virtual communities }\end{array}$
\end{tabular}

Wiertz \& deRuyter Theory of reasoned expected return on knowledge sharing, absorptive (2007); Nambisan \& Bar- action ability and self-evaluation. People behave in a rational on (2007); Wasko \& Faraj (2005) way and when they take up a given activity they consider the possible consequences of their action and the possessed knowledge about the consequences and the so-called subjective norms lie at the heart of the intention, which precedes a given behavior

Jeppesen \& Frederiksen Theory of planned inclination to trust, benefits of learning, social ben(2006); Roberts et al., behavior

(2006); Wasko \& Faraj,

(2000); Nambisan \& efits, contentment, appreciation by other members of the virtual community, appreciation by the organization

Baron (2007, 2009); Hsu et al. (2007)

Pierro et al. (2008); Spin- Inventory of work external and internal motivation deldreher \& Schlagwein preference (2016) Heo \& Toomey (2015)

Social comparison need for assessing one's own abilities, features in ortheory der to obtain an accurate vision of oneself 


\begin{tabular}{|c|c|c|}
\hline Author(s) & Way of measuring & Measurement metrics \\
\hline Lai \& Chen (2014) & $\begin{array}{l}\text { Extrinsic motivation, } \\
\text { intrinsic motivation, } \\
\text { and intracommunity } \\
\text { factors }\end{array}$ & $\begin{array}{l}\text { harmony, reputation, mutuality, joy in helping others, } \\
\text { knowing ones' efficiency }\end{array}$ \\
\hline Cheung et al. (2013) & $\begin{array}{l}\text { Social cognitive } \\
\text { theory and expecta- } \\
\text { tion disconfirmation } \\
\text { theory }\end{array}$ & knowing one's efficiency \\
\hline Oh (2012) & $\begin{array}{l}\text { Social exchange } \\
\text { theory and weak tie } \\
\text { theory }\end{array}$ & $\begin{array}{l}\text { harmony, reputation, mutuality, joy in helping others, } \\
\text { knowing ones' efficiency }\end{array}$ \\
\hline Chang \& Chuang (2011) & Social capital theory & $\begin{array}{l}\text { harmony, reputation, mutuality, joy in helping others, } \\
\text { trust }\end{array}$ \\
\hline Ho et al. (2011) & $\begin{array}{l}\text { Theory of planned } \\
\text { behavior }\end{array}$ & $\begin{array}{l}\text { reciprocity, enjoyment in helping others, peer influ- } \\
\text { ence, knowledge self-efficacy, resource availability. }\end{array}$ \\
\hline $\begin{array}{l}\text { Jeon, Kim, and Koh } \\
(2011)\end{array}$ & $\begin{array}{l}\text { Theory of planned } \\
\text { behavior model, mo- } \\
\text { tivation theory }\end{array}$ & $\begin{array}{l}\text { reputation, reciprocity, enjoyment in helping others, } \\
\text { resource availability. }\end{array}$ \\
\hline \multirow[t]{2}{*}{ Cho et al. (2010) } & $\begin{array}{l}\text { Theory of planned } \\
\text { behavior }\end{array}$ & $\begin{array}{l}\text { reputation, reciprocity, enjoyment in helping other, } \\
\text { knowledge }\end{array}$ \\
\hline & & self-efficacy \\
\hline \multirow[t]{2}{*}{ Chen \& Hung (2010 } & $\begin{array}{l}\text { Social exchange the- } \\
\text { ory and social capital }\end{array}$ & $\begin{array}{l}\text { perceived usefulness, compatibility, reciprocity, inter- } \\
\text { personal trust, knowledge }\end{array}$ \\
\hline & theory & self-efficacy \\
\hline Tseng \& Kuo (2010) & $\begin{array}{l}\text { Social cognitive the- } \\
\text { ory and social capital } \\
\text { theory }\end{array}$ & interpersonal trust, knowledge self-efficacy \\
\hline $\begin{array}{l}\text { Phang, Kankanhalli \& } \\
\text { Sabherwal (2009) }\end{array}$ & $\begin{array}{l}\text { Social exchange } \\
\text { theory }\end{array}$ & perceived ease of use \\
\hline Marett \& Joshi (2009) & $\begin{array}{l}\text { Self-determination } \\
\text { theory }\end{array}$ & reputation, reciprocity \\
\hline \multirow[t]{2}{*}{ Lin et al. (2009) } & $\begin{array}{l}\text { Social cognitive the- } \\
\text { ory }\end{array}$ & $\begin{array}{l}\text { perceived usefulness, compatibility; reciprocity; inter- } \\
\text { personal trust, knowledge }\end{array}$ \\
\hline & & self-efficacy; \\
\hline Hsu et al. (2007) & $\begin{array}{l}\text { Social cognitive the- } \\
\text { ory }\end{array}$ & trust, knowing one's own efficiency \\
\hline Chiu et al. (2006) & $\begin{array}{l}\text { Social cognitive the- } \\
\text { ory and social capital } \\
\text { theory }\end{array}$ & mutuality, trust \\
\hline Wasko \& Faraj (2005) & $\begin{array}{l}\text { Social exchange the- } \\
\text { ory and social capital } \\
\text { theory }\end{array}$ & reputation, mutuality, joy in helping others \\
\hline
\end{tabular}

The psychological models assume that the behaviors of virtual communities depend on individual motivations (Wasko \& Faraj, 2000), expected benefits, attitudes towards knowledge sharing and the readiness to trust other members of the virtual community. Therefore, it is a mixture of inclination to trust, motivation, and actual knowledge sharing. 
The Cognitive Evaluation Theory assumes that in favourable conditions the internal motivation for action will develop. The social context of events is contributory, for example: feedback, communication, or awards. A feeling of competence will not cause an increase in motivation - however a feeling of internal autonomy may strengthen the chances for motivation to appear. The competences and autonomy play a critical role here. Few authors make use of this theory to analyse virtual knowledge sharing. Zhao and Zhu (2012) developed a conceptual model of using this theory to study the participation of the virtual community in crowdsourcing. In the authors' opinion, this theory enables the identification of a participant's motivation in sharing knowledge in crowdsourcing platforms. Crowdsourcing contributes to autonomy, development of competences, relationship and leadership of the virtual communities. It also enables: analysing, explaining, predicting, explaining and predicting, and design. However, this proposal has never been tested.

The essence of the Self-Determination Theory is the three psychological needs of the human being, which constitute the basis of motivation, i.e.: autonomy, competence, and relationship. The need for autonomy assumes a longing for experiencing a psychological freedom of behavior (Deci \& Ryan, 2000). The need for competence includes a will to achieve or interact, without unwanted effects. The need for relationship refers to the will to establish cooperation with others who have similar interests. According to the Self-Determination Theory satisfying those needs has an influence which is motivating and encouraging for taking action. Research on virtual knowledge sharing in the context of this theory was conducted by Jacobs (2016). The research question was: to what extent does knowledgesharing behavior within a Virtual Community of Practice relate to perceived autonomy, competence and relatedness at work, and the employees' level of commitment to the organization? The research covered 270 employees at Rabobank of Rijk van Nijmegen. The variable level of activity was measured using a scale developed by Lin, Hung and Chen (2009). The scale consisted of four items that took the form of statements which were anchored by a sevenpoint Likert scale. The author considers this theory is suitable for research on virtual knowledge sharing since it includes the issue of involvement in knowledge sharing, which is often omitted by other authors. Yoon and Rolland (2012) conducted research into the scope of behaviors related to knowledge sharing. The research model was tested with data from a crosssectional survey of virtual community members collected from Korea. The questionnaire contained measurements for perceived autonomy, perceived competence, and perceived relatedness adapted from the Basic Need Satisfaction Scale developed by Deci and Ryan (2000). The measurements for familiarity construct were adapted from Gefen's study. The items for 
perceived anonymity were adapted from Chua \& Jiang's study, and the items for knowledge sharing behavior were adapted from Lin et al.'s study. The proposed questionnaire takes into account all issues connected with virtual knowledge sharing. Lai and Chen (2014) used the scale of reputation by Kankanhalli et al. (2005) to identify motivating factors, mutuality by Davenport and Prusak (1998), joy in helping others by Wasko and Faraj (2000), knowledge of own efficiency by Spreitzer (1996), enthusiasm by Koh and Kim (2003), online activity by Jang and Ko (2010), joy by Koh and Kim (2003), and intention of sharing knowledge by Ajzen (1991). The research covered 324 users of the Mobile01 platform. The authors also made reference to the theory of Deci and Ryan, 1980, according to which a person internally motivated more willingly engages in actions.

The theory of reasoned action and the theory of planned behavior (Ajzen, 1991) are used for understanding the behaviors of Internet store customers, but also for evaluating intentions in knowledge sharing. Within the theory of reasoned action people behave in a rational way and while taking up a given activity they consider the potential consequences of their action and the possessed knowledge about the consequences and the socalled subjective norms lie at the heart of the intention which precedes a given behavior. The theory of planned behavior (Ajzen, 1991) assumes that knowledge sharing may be measured using factors, which impact behavior, i.e.: 1) attitude toward the behavior, (2) social norms regarding the behavior, and (3) beliefs about one's control over the behavior. An attitude is considered to be the degree, which evaluates a behavior as positive or unfavourable. A subjective norm is the perceived social pressure, whereas control beliefs concern the possessed skills, resources, and possibilities of getting involved in a behavior. If the control beliefs reflect the actual influence of an individual on a situation, it may be treated as a direct predictor of the behavior. If, however, it does not reflect the actual control, it determines the behavior in an indirect way. Sciences have used this theory to analyse knowledge-sharing behavior (Bock, Zmud, Kim \& Lee, 2005). For instance Martinez (2017) used this theory to study the motivation of virtual communities in the scope of creating in crowdsourcing, taking into account the indirect role of trust towards a platform. In the author's opinion it may decrease unsurety and favour knowledge sharing. The empirical setting of this paper is Kaggle (www. kaggle.com), the world's leading online platform for predictive modelling competitions. Participation intention refers to the solver's willingness to participate in prediction competitions.

According to the Theory of Planned Behavior (TPB) (Ajzen, 1991), the stronger the intention is the more likely it will be to participate. For the measurement the author created her own measurement tool composed 
of the following elements: autonomy, variability of tasks, complexity of competition, solving of tasks, specialization (Morgeson \& Humphrey, 2006), internal motivation, intention to act (Zeng et al., 2011), and trust. Although the tool includes virtual knowledge sharing, the questions focus more on the motivation of the virtual community to create innovative solutions. Bakici, Almirall and Wareham (2013) deemed that the theory of planned behavior will provide a very good foundation for us to investigate the motivations of participators to open innovation intermediaries. In their research, intention is referred to as an individual's willingness to participate in open innovation intermediaries. To test the Theory of Planned Behavior model in an open innovation intermediary context, they conducted a Web-based survey on the Atizo community. The measurement scale included the following components: Intrinsic Rewards, Extrinsic Rewards, Participation, Attitude, Perceived Behavioral Control, Subjective Norm, and Intention to Participate. The authors discovered that development, play, pleasure, membership in the community, and reputation - constitute the motivation to participate in virtual communities. The applied tool did not focus on virtual knowledge sharing. The scale takes into account the intention to share knowledge Marett \& Joshi (2009) ("KSI1" If I had some knowledge about a topic, I would consider posting it on the online community website", "KSI2 If I had some knowledge regarding a question someone asked, I would share this knowledge with others") - which does not reflect the idea of virtual knowledge sharing. Kosonen et al. (2014), based on the above-mentioned theories, constructed their own research tool - a questionnaire posted on the Internet (Likert's 7-point scale). 283 Internet users participated in the research study (39 questionnaires were rejected; the return rate was $83.3 \%$ ). The following measurements were included in the research study: an inclination to trust, benefits of learning, social benefits, contentment, appreciation on the part of the other members of the virtual community, and appreciation by the organization. The tool seems to be complete because it takes into account the ascertainment's of the predecessors.

The Work Preference Inventory (WPI) is a tool for measuring virtual knowledge sharing in crowdsourcing. It is intended for an individual assessment of the internal (self-determination, competences, involvement in tasks, curiosity, joy) and external (competing, evaluation, recognition, money or other material incentives) motivation factors. This tool enables self- assessment of the perception of these motivators. It is composed of seven elements referring to a feeling of pleasure, seven related to a feeling of challenge, five connected with a will to receive an award, and ten related to the longing for apprehension. In the questionnaire, Likert's 6-degree scale is usually used. In the Work Preference Inventory there are no questions related to virtual knowledge sharing. It is also difficult to perform the measurement 
since its construction enables only a self-assessment of one's behavior by each member of the virtual community.

The social comparison theory indicates that people engage in actions, which enable them to get to know their own abilities and confronting them with others. It is then when self-evaluation (assessment of comparative personal standing), self-enhancement (self-esteem), and self-improvement (ability) are made. This contributes to increasing self-awareness and satisfies the longing for becoming similar to others. This is done in a situation when there is no objective standard according to which one may assess oneself and when there is no certainty about how we are in a given respect. Then comparison takes place with persons who place themselves higher in relation to a given skill or feature. According to this theory, a standard of perfection which the other person wants to pursue is specified. An assimilation of skills occurs. In virtual knowledge sharing members of virtual communities adapt their behavior according to the group's norm. This theory, as well as the Self-Determination Theory to study motivation in the scope of knowledge sharing in crowdsourcing, was used by Heo \& Toomey (2015). It seems that an integration of these two theories may constitute a good solution in the context of studying virtual knowledge sharing in crowdsourcing.

In the Social Exchange Theory, human interactions are a process in which an exchange of valuable resources takes place. The idea of mutuality is important here. According to this point of view, even in seemingly completely altruistic, philanthropic, and selfless actions there is a hidden - not always realized - will to gain something in return: admiration, prestige, fame, or trust. What is important is the bilateral, mutually conditional, and satisfying exchange (Wasko \& Faraj, 2005). In this perspective, sharing knowledge in virtual communities means personal behaviors and a type of exchange between members, which takes on the form of long-term relations. The knowledge resources for each member may lose their useful value, but become beneficial to other members. That is why people devote their time, so that others may enjoy these resources (Wasko \& Faraj, 2005). This theory was used in research by Jinyang (2015). He surveyed 240 students, doctoral students, and scientific and didactic workers experienced in the scope of knowledge sharing in virtual communities. He used a questionnaire with Likert's 5-degree scale. Items on reciprocity are adapted from Wasko \& Faraj (2005); Items on trust are gained from Chiu et al. (2006); Altruism ideas derive from Chang \& Chuang (2011) and Kankanhalli, Tan \& Wei (2005); Sharing willingness ideas are adapted from Davenport \& Prusak (1998); Items on sharing behaviors are adapted from Hsua et al. (2007). The obtained results indicate that the most important factor of virtual knowledge sharing is willingness and readiness to share. Trust, mutuality, and altruism are less important. By the same token the theory of social comparisons cannot unambiguously explain 
virtual knowledge sharing. The author points out that future research should include psychological and environmental variables. Only a few ascertain that social exchange is the most popular theory in explaining knowledge sharing behavior. The tool adopted by Jinyang (2015) takes into account readiness to share knowledge (attitude for sharing knowledge, expectation for sharing knowledge, mutuality, mutual motivation, awards), altruism (individual efficiency, sharing efficiency), trust (interactions, coordination), sharing behavior (individual norms, behavior intentions). It may constitute a good base for studying virtual knowledge sharing.

Few authors, based on the existing theories, developed their own measuring tools. For instance the model of online knowledge sharing by Ma \& Yuen (2011) assumes measuring virtual knowledge sharing in the context of learning and assessment of application components. The authors take into consideration particularly the degree to which a given person thinks that she or he can improve the goods in a social dimension, interact, build a feeling of unity with other users - owing to which they will be more inclined to be involved in Internet learning (Perceived Online Attachment Motivation Sources). In this approach all members of the virtual community have a common goal, which is learning, knowledge sharing, and developing of relations. This is not limited to discussions and meetings, but also observations, imitations, and exercises thanks to using an online platform. In addition, what gains importance is involvement, which reflects an internal perception of another person (Perceived Online Relationship Commitment). This is connected with the degree to which an individual believes she or he may maintain contacts with other Internet users - by the same token the greater the need of an individual for building relations, the greater the involvement in online communities and devoted time is. Knowledge sharing in this model is a way to establish close relations and it may be perceived as some kind of social support and a form of prosocial behavior. Within the maintaining of good relations, each member of the virtual community becomes more inclined to share knowledge with the other members of the Internet community. Nonetheless, the authors point out to some limitations: the model was tested in an online learning environment in Hong Kong, it is limited only to three constructs, it does not take into account people's behavior in learning, and so future research should consider additional variables which influence the process of online knowledge sharing. The authors suggest making reference to the self-determination theory, which suggests taking into account the autonomy, competences, and relation - as the three basic needs and determinants of quality, good state of mind, and satisfaction (Patrick et al., 2007; Deci \& Ryan, 2000). 


\section{DISCUSSION AND CONCLUSIONS}

The aim of the article was to present the existing output connected with the ways of measuring virtual knowledge sharing within crowdsourcing. In addition, the importance of searching for an answer to the question - why it is worth studying community knowledge sharing - was indicated. Based upon the conducted analysis, a number of conclusions may be drawn:

1) In the literature, various ways of measuring are indicated, which focus on an analysis of behaviors of the virtual communities. However, they only partially focus on virtual knowledge sharing.

2) It is difficult to apply most of them to the measurement. Most of them are of a theoretical nature only and they have never been tested. An interesting solution from a scientific point of view may be the proposal of Jacobs (2016). Based on the Self-Determination Theory the author additionally took into account the issues of involvement in knowl edge sharing. Few ascertain that social exchange is the most popular theory in explaining knowledge sharing behavior. This may constitute a good basis for research on virtual knowledge sharing. Others suggest combining two theories: Social comparison theory and Self-Determination Theory. Few authors, based upon the existing theories, developed their own measuring tools - the model of online knowledge sharing by Ma \& Yuen (2011), which however does not include people's behavior in learning. It seems that the most complete and useful is the tool developed by Kosonen et al. (2014) - since it takes into account the findings of the predecessors and the theory of reasoned action and the theory of planned behavior. In addition, it contains not only forming individual intentions to share knowledge, but also the actual knowledgesharing behavior, in the light of current research.

3. The conducted review of tools enables one to ascertain that the studies on virtual knowledge sharing are more and more popular and that surely the next variants of measuring this construct will appear in the literature. The first dilemma appears against this background: not all tools are able to fully study the essence of this process. Whereas, the second dilemma concerns the cognitive limits of virtual knowledge sharing and losing important information as a result of too many measures of a multidimensional nature.

\section{Future research}

The results of the review of existing tools for measuring virtual knowledge sharing confirm that this measurement is complicated and difficult. Not all existing ways match with the specificity of virtual communities in crowdsourcing. The majority of the research studies focus on identifying 
the factors, which encourage the sharing of knowledge, while the issue and specificity of crowdsourcing is omitted. As it has already been stated the crowd or virtual community is the necessary condition for crowdsourcing to occur. That is why it is important to specify the relations between this level and crowdsourcing, in particular in the scope of the course of virtual knowledge sharing. The conducted review should act as an introduction to carrying out furtherpilot research that would verify the usefulness of the indicated tool in the crowdsourcing platforms' environment. Generally speaking, future research should take into consideration the above-mentioned limitations. While indicating the future research areas related to virtual knowledge sharing it ought to be borne in mind that it should be analysed taking into account the specificity of crowdsourcing (Nooteboom, 2000).

\section{Implications}

The review of the literature and research results leads to a number of conclusions useful for managers and business practice. Firstly, managers must bear in mind the importance of crowdsourcing and virtual communities. Secondly, a constant measurement of virtual community behaviors, particularly in the context of knowledge sharing - enables diagnosing the correctness of tasks directed to the crowd, assessment of the crowdsourcing platform's efficiency, which is connected with optimising costs and maximising benefits. It should be emphasized that the role of the organization-initiator is directing to the crowd, through a crowdsourcing platform, an open call for collaboration and defining the tasks expected to be solved. It is important here that the initiator specifies the goal, scope, schedule, expectations, awards, or a group of recipients. The initiator should also, during the project's course, exercise control over its process, e.g. evaluate the incoming ideas/ solutions, answer the participants' questions. It is worth noting that from the initiator's point of view there are measurable benefits of crowdsourcing, among others: access to talents, external knowledge, valuable information, resources, skills and experience, mobilization, and competences. This may be used for organizational learning, openness of the organization to new external knowledge, creating open innovations, building competitive advantage, improving business processes, optimising the organization's activity costs, or business models. However, without measuring the behaviors of virtual communities, in particular in the scope of - these benefits are difficult to achieve. 


\section{Acknowledgments}

This project was financed from the funds provided by the National Science Centre, Poland awarded on the basis of decision number DEC-2016/21/D/ HS4/01791.

\section{References}

Ajzen, I. (1991). The theory of planned behavior. Organizational Behavior and Human Decision Processes, 50(2), 179-211.

Alavi, M., \& Leidner, D. E. (2001). Review. Knowledge management and knowledge management systems: Conceptual foundations and research issues. MIS Quarterly, 25(1), 107-136.

Almirall, E., \& Wareham, J. (2011). Living labs: Arbiters of mid- and groundlevel innovation. Technology Analysis \& Strategic Management, 23(1), 87-102.

Arthur, J.B., \& Huntley, C.L. (2005). Ramping up the organizational learning curve: Assessing the impact of deliberate learning on organizational performance under gainsharing. Academy of Management Journal, 48(6), 1159-1170.

Bakici, T., Almirall, E., \& Wareham, J. (2013). A smart city initiative: The case of Barcelona. Journal of the Knowledge Economy, 4(2), 135-148.

Basto, D., Flavin, T., \& Patino, C. (2010). Crowdsourcing public policy innovation. Working Paper, Heinz College Carnegie Mellon University.

Bock, G.-W., Zmud, R.W., Kim, Y.-G., \& Lee, J.-N. (2005). Behavioral intention formation in knowledge sharing: Examining the roles of extrinsic motivators, social-psychological forces, and organizational climate. MIS Quarterly, 29(1), 87-111.

Bollinger, A.S., \& Smith, R.D. (2001). Managing organizational knowledge as a strategic asset. Journal of Knowledge Management, 5(1), 8-18.

Brabham, D.C. (2008). Crowdsourcing as a model for problem solving: An introduction and cases, convergence. The International Journal of Research into New Media Technologies, 14(1), 75-90.

Chang, H.H., \& Chuang, S.S. (2011). Social capital and individual motivations on knowledge sharing: Participant involvement as a moderator. Information \& Management, 48(1), 9-18.

Charband, Y., \& Navimipour, N.J. (2016). Online knowledge sharing mechanisms: A systematic review of the state of the art literature and recommendations for future research. Journal Information Systems Frontiers, 6(18), 1131-1151.

Chen, H.-R., \& Huang, H.-L. (2010). User acceptance of mobile knowledge management learning system: Design and. analysis. Educational Technology \& Society, 13(3), 70-77.

Cheung, Ch., Lee, M.K.O., \& Lee, Z.W.Y. (2013). Understanding the continuance intention of knowledge sharing in online communities of practice through the post-knowledge-sharing evaluation processes. Journal of 
the American Society for Information Science and Technology, 64(7), 1357-1374.

Chiu, C.-M., Hsu, M.-H., \& Wang, E.T.G. (2006). Understanding knowledge sharing in online communities: An integration of social capital and social cognitive theories. Decision Support Systems, 42(3), 1872-1888.

Chua, Z., \& Jiang, Z. (2006). Effects of anonymity, media richness, and chatroom activeness on online chatting experience. ECIS 2006 Proceedings. 153. Retrieved fromhttps://aisel.aisnet.org/ecis2006/153

Collins, C.J., \& Smith, K.G. (2006). Knowledge exchange and combination: The role of human resource practices in the performance of high-technology firms. Academy of Management Journal, 49(3), 544-560.

Cummings, J.N. (2004). Work groups, structural diversity, and knowledge sharing in a global organization. Management Science, 50(3), 352-364.

Cupido, K., \& Ophoff, J. (2014). A conceptual model of critical success factors for an egovernment crowdsourcing solution. Electronic Journal of e-Government, 12(2), 142-157.

Davenport, T.H., \& Prusak, L. (1998). Working Knowledge: How Organizations Manage What They Know. Boston: Harvard Business School Press.

De Kerckhove, D. (2001). Inteligencja Otwarta. Narodziny Społeczeństwa Sieciowego. Warszawa: Wydawnictwo Mikom.

Deci, E.L., \& Ryan, R.M. (2000). The 'what' and 'why' of goal pursuits: Human needs and the self-determination of behavior. Psychological Inquiry, 11, 227-268.

Din, N., \& Haron, S. (2012). Knowledge sharing as a culture among Malaysian online social networking users. Proceeding paper of ASEAN Conference on Environment-Behavior Studies, 16 -17 July 2012, Bangkok.

Faraj S., Jarvenpaa S.L., \& Majchrzak, A. (2011). Knowledge collaboration in online communities. Organization Science, 22(5), 1224-1239.

Fishbein, M., \& Ajzen, I. (1974). Attitudes toward objects as predictors of single and multiple behavioral criteria. Psychological Review, 81, 59.

Franke, N., Von Hippel, E., \& Schreier, M., (2006). Finding commercially attractive user innovations: A test of lead-user theory. Journal of Product Innovation Management, 23(4), 301-315.

Fuchs, C., \& Schreier, M. (2011). Customer empowerment in new product development. Journal of Product Innovation Management, 28, 17-32.

Füller, J., \& Matzler, K. (2007). Virtual product experience and customer participation. A chance for customer-centered, really new products. Technovation, 27(6-7), 378-387.

Hansen, M.T. (2002). Knowledge networks: Explaining effective knowledge sharing in multiunit companies. Organization Science, 3(13), 232-248.

Heo, M., \& Toomey, N. (2015). Motivating continued knowledge sharing in crowdsourcing: The impact of different types of visual feedback. Online Information Review, 6(39): 795-811. 
Ho, S., Ting, P., Bau, D., \& Wai, C. (2011). Knowledge sharing intention in a virtual community: A study of participants in the Chinese Wikipedia. Cyberpsychology Behavior and Social Networking, 14, 541-545.

Hong, P., Doll, W.J., Revilla, E., \& Nahm, A.Y. (2011). Knowledge sharing and strategic fit in integrated product development projects: an empirical study. International Journal of Production Economics, 132, 186-196.

Howe, J. (2006). The rise of crowdsourcing. Wired Magazine, 14(6), 1-4.

Hsu, M. H., Ju, T.L., Yen, C.H., \& Chang, C.M. (2007). Knowledge sharing behavior in virtual communities: The relationship between trust, selfefficacy, and outcome expectations. International Journal HumanComputer Studies, 65(2), 153-169.

Hung, S.-Y., Lai, H.-M., \& Chou, Y.-Ch. (2015). Knowledge-sharing intention in professional virtual communities: A comparison between posters and lurkers. Journal of the Association for Information Science and Technology, 12(66), 2494-2510.

Ipe, M. (2003). Knowledge sharing in organizations: A conceptual framework. Human Resource Development Review, 4, 337-359.

Jacobs, R. (2016). The relation between knowledge-sharing behavior within a virtual community of practice and employees' organizational commitment. Retrieved from https://theses.ubn.ru.nl/bitstream/ handle/123456789/828/Jacobs\%2C\%20Renske\%204241886\%20BA\%20 werkstuk.pdf?sequence $=1$

Jeon, S., Kim, Y.-G., \& Joon Koh, J. (2011). An integrative model for knowledge sharing in communities of practice. Journal of Knowledge Management, 2(15), 251-269.

Jeppesen, L.B., \& Frederiksen, L. (2006). Why do users contribute to firmhosted user communities? The case of computer-controlled music instruments. Organization Science, 17(1), 45-63.

Jinyang, L. (2015). Knowledge sharing in virtual communities: A social exchange theory perspective. Journal of Industrial Engineering and Management, 8(1), 170-183.

Kankanhalli, A., Tan, B.C.Y., \& Wei, K.K. (2005). Contributing knowledge to electronic knowledge repositories: An empirical investigation. Mis Quarterly, 29(1), 113-143.

Kleeman, F., Gunter, Voss G., \& Rieder, K. (2008). Un(der)paid innovators: The commercial utilization of consumer work through crowdsourcing. Science, Technology \& Innovation Studies, 4(1), 5-26.

Ko, D., Kirsch, L., \& King, W. (2005). Antecedents of knowledge transfer from consultants to clients in enterprise system implementations. MIS Quarterly, 29(1), 59-85.

Koh, J., \& Kim, Y.G. (2003). Sense of virtual community: A conceptual framework and empirical validation. International Journal of Electronic Commerce, 8, 75-93. 
Kosonen, M., Chunmei, G., Vanhala, M., \& Blomqvist, K. (2014). User motivation and knowledge sharing in idea crowdsourcing. International Journal of Innovation Management, 18(05), 1-23.

Kowalczyk, A., \& Nogalski, B. (2007). Zarządzanie Wiedzą. Koncepcja i Narzędzia, Warszawa: Difin.

Kowalska, M. (2015). Crowdsourcing Internetowy - Pozytywny Wymiar Partycypacji Społecznej. Konteksty-istota-uwarunkowania. Warszawa: Wydawnictwo Stowarzyszenie Bibliotekarzy Polskich.

Kożuch, B., \& Lenart-Gansiniec, R. (2016). Uwarunkowania skutecznego dzielenia się wiedzą na uczelni. Zarzq̨dzanie Publiczne, 4(36), 303-320.

Krupski, R., Niemczyk, J., \& Stańczyk-Hugiet, E. (2009). Koncepcje Strategii Organizacji. Warszawa: PWE.

Lai, H.-M., \& Chen, T. T. (2014). Knowledge sharing in interest online communities: A comparison of posters and lurkers. Computers in Human Behavior, 35, 295-306.

Lee, F.S., Vogel, D. \& Limayem, M. (2003). Virtual community informatics: A review and research agenda. Journal of Information Technology Theory and Application, 1(5), 47-61.

Leimeister, J.M., \& Zogaj, S. (2013). Neue Arbeitsorganization durch Crowdsourcing, Hans-Böckler-Stiftung. Arbeitspapier Arbeit und Soziales, 287.

Li, W., Downey, S., \& Wentling, T. (2008). Online knowledge sharing in a multinational corporation: Chinese versus American practices. Proceedings of the American Society for Information Science and Technology, 44, 1-13.

Liao, L.-F. (2006). A learning organization perspective on knowledge-sharing behavior and firm innovation. Human Systems Management, 25(4), 227.

Lin, M.J.J., Hung, S.W., \& Chen, C.J. (2009). Fostering the determinants of knowledge sharing in professional virtual communities. Computers in Human Behavior, 25, 929-939.

Liu, C., Liang, T., Rajagopalan, B., \& Sambamurthy, V. (2011). The crowding effect of rewards on knowledge-sharing behavior in virtual communities. PACIS 2011 Proceedings, 116. Retrieved from https://aisel.aisnet.org/ pacis2011/116

Lodge, M., \& Wegrich, K. (2014). Crowdsourcing and regulatory reviews: A new way of challenging red tape in British government? Regulation \& Governance, 9, 30-49.

Lu, Y., Zhao, L., \& Wang, B. (2010). From virtual community members to $\mathrm{C} 2 \mathrm{C}$ e-commerce buyers: Trust in virtual communities and its effect on consumers' purchase intention. Electronic Commerce Research and Applications, 9, 346-360.

Ma, W.K., \& Yuen, A.H.K. (2011). Gender differences of knowledge sharing in online learning environment. In R. Kwan, J. Fong, Lam-for Kwok \& J. Lam (Eds.), Hybrid Learning (pp. 116-128). Berlin Heidelberg: Springer-Verlag. 
Ma, W.W.K., \& Yuen, A.H.K. (2010). Understanding online knowledge sharing: An interpersonal relationship perspective. Computers \& Education, 56(1), 210-219.

Majchrzak, A., \& Malhotra, A. (2013). Towards an information systems perspective and research agenda on crowdsourcing for innovation. The Journal of Strategic Information Systems, 22(4), 257-268.

Marett, K., \& Joshi, K.D. (2009). The decision to share information and rumors: Examining the role of motivation in an online discussion forum. Communications of the Association for Information Systems, 24, 47-68.

Martinez, M.G. (2017). Inspiring crowdsourcing communities to create novel solutions: Competition design and the mediating role of trust. Technological Forecasting and Social Change, 117, 296-304.

Mazzola, D., \& Distefano, A. (2010). Crowdsourcing and the participation process for problem solving: The case of BP. Proceedings of ItAIS $2010 \mathrm{VII}$ Conference of the Italian Chapter of AIS, 42-49.

Mazzolini, M., \& Maddison, S. (2007). When to jump in: The role of the instructor in online discussion forums. Computers and Education, 49, 193-213.

Mesmer-Magnus, J.R., \& DeChurch, L.A. (2009). Information sharing and team performance: A meta-analysis. Journal of Applied Psychology, 94, 535-546.

Morgeson, F.P., \& Humphrey, S.E. (2006). The Work Design Questionnaire (WDQ): Developing and validating a comprehensive measure for assessing job design and the nature of work. Journal of Applied Psychology, 91, 1321-1339.

Murphy, L.P. (1997). Web 'communities' a target marketer's dream. Marketing News, 31, 2-3.

Nambisan, S., \& Baron, R.A. (2007). Interactions in virtual customer environments: implications for product support and customer relationship management. Journal of Interactive Marketing, 21(2), 42-62.

Nambisan, S., \& Baron, R.A. (2009). Virtual customer environments. Testing a model of voluntary participation in value co-creation activities. The Journal of Product Innovation Management, 4(26), 388-406.

Nissen, M. E. (2007). Knowledge management and global cultures: Elucidation through an institutional knowledge-flow perspective. Knowledge and Process Management, 14(3), 211-225.

Nonaka, I., \& Takeuchi, H. (1995). The knowledge-creating company, New York, Oxford: Oxford University Press.

Nooteboom, B. (2000). Learning and Innovation in Organizations and Economies. Oxford: Oxford University Press.

Oh, S. (2012). The characteriztics and motivations of health answerers for sharing information, knowledge, and experiences in online environments. Journal of the American Society for Information Science and Technology, 63(3), 543-557. 
Pańkowska, M. (2007). Programy badań i rozwoju technologicznego jako środowisko powstawania społeczności wirtualnych. In W.H. Sroka \& T. Porębska-Miąc (Eds), Systemy Wspomagania Organizacji SWO'2007. Katowice: Wydawnictwo Akademii Ekonomicznej.

Patrick, H., Knee, C. R., Canevello, A., \& Lonsbary, C. (2007). The role of need fulfilment in relationship functioning and well-being: A selfdetermination theory perspective. Journal of Personality and Social Psychology, 92, 434-457.

Phang, C. W., Kankanhalli, A., \& Sabherwal, R. (2009). Usability and sociability in online communities: A comparative study of knowledge seeking and contribution. Journal of the Association for Information Systems, 10(10), 721.

Pichlak, M. (2012). Otwarte innowacje jako nowy paradygmat w zarządzaniu innowacjami. Zeszyty Naukowe. Organizacja i Zarzqdzanie, 60, 281-292.

Pierro, A., Cicero, L., \& Raven, B. (2008). Motivated compliance with bases of social power. Journal of Applied Social Psychology, 38(7), 1921-194.

Preece, J. (2000). Online Communities. Designing Usability, Supporting Sociability, Chichester: Wiley.

Quigley, N.R., Tesluk, P.E., Locke, E.A., \& Bartol, K.M. (2007). A multilevel investigation of the motivational mechanisms underlying knowledge sharing and performance. Organization Science, 18(1), 71-88.

Reychav, I., \& Weisberg, J. (2009). Going beyond technology: Knowledge sharing as a tool for enhancing customer-oriented attitudes. International Journal of Information Management, 29(5), 353-361.

Rheingold, H. (1993). The Virtual Community: Homesteading on the Electronic Frontier. Reading, MA: Addison-Wesley.

Roberts, J., Hann, I., \& Slaughter, S. (2006). Understanding the motivations, participation and the performance of open source software developers: A longitudinal study of the Apache projects. Management Science, 52(7), 984-999.

Romm, C.T., Pliskin, N. \& Clarke, R.J. (1997). Virtual communities and society: Toward an integrative three phase model. International Journal of Information Management, 17(4), 261-270.

Rudawska, A. (2013). Dzielenie się wiedzą w organizacjach - istota, bariery i efekty. Organizacja i Kierowanie, 4(157), 89-103.

Ryan, R. M., \& Deci, E. L. (2000). Self-determination theory and the facilitation of intrinsic motivation, social development, and well-being. American Psychologist, 55, 68-78.

Salisbury, M. W. (2003). Putting theory into practice to build knowledge management systems. Journal of Knowledge Management, 7(2), 128-141.

Sawhney, M., Verona, G., \& Prandelli, E. (2005). Collaborating to create: The Internet as a platform for customer engagement in product innovation. Journal of Interactive Marketing, 19, 4-17.

Sharratt, M., \& Usoro, A. (2003). Understanding knowledge-sharing in online communities of practice. European Journal of Knowledge Management, 1, 18-29. 
Sloane, P. (2011). A Guide to Open Innovation and Crowdsourcing: Advice from Leading Experts, UK: Kogan Page Publishers.

Spindeldreher, K., \& Schlagwein, D. (2016). What drives the crowd? A metaanalysis of the motivation of participants in crowdsourcing. PACIS, 119.

Spreitzer G. M. (1996). Social structural characteriztics of psychological empowerment. Academy of Management Journal, 39, 483-504.

Stewart, O., Huerta, J., \& Sader, M. (2009). Designing crowdsourcing community for the enterprise. Proceedings of the ACM SIGKDD Workshop on Human Computation ACM. New York, USA.

Surowiecki, J. (2004). The Wisdom of Crowds: Why the Many are Smarter than the Few and How Collective Wisdom Shapes Business, Economies, Societies, and Nations. New York: Doubleday.

Tseng, F.--, \& Ch., \& Kuo (2010). A study of social participation and knowledge sharing in the teachers' online professional community of practice. Journal Computers \& Education, 72, 37-47.

Usoro, A., Sharratt, M.W., Tsui, E., \& Shekhar, S. (2007). Trust as an antecedent to knowledge sharing in virtual communities of practice. Knowledge Management Research \& Practice, 5(3), 199-212.

Van den Hooff, B., \& De Leeuw van Weenen, F. (2004). Committed to share: Commitment and CMC use as antecedents of knowledge sharing. Knowledge and Process Management, 11(1), 13-24.

Van den Hooff, B., \& De Ridder, J.A. (2004) Knowledge sharing in context; The influence of organizational commitment, communication climate and $\mathrm{CMC}$ use on knowledge sharing. Journal of Knowledge Management, 8(6), 117-130.

Van Doodewaard, M. (2006). Online knowledge sharing tools: any use in Africa? Knowledge Management for Development, 2, 40-47.

Verburg, R.M., \& Andriessen, E.J.H. (2011). A typology of knowledge sharing networks in practice. Knowledge and Process Management, 18(1), 3444.

Von Hippel, E., Ogawa, S., \& de Jong, J.P.J. (2011). The age of the userinnovator. Sloan Management Review, 53(1), 27-35.

Vukovic, M., Mariana, L., \& Laredo, J. (2009). People cloud for the globally integrated enterprise. In D. Asit, F. Gittler \& F. Tourmani (Eds.), Serviceoriented computing. Berlin: Springer.

Wadhwa, A., \& Koth S. (1999), A note on virtual communities. Retrieved from https://faculty.washington.edu/skotha/website/cases\%20pdf/virtual_ communities

Wang, S., \& Noe, R.A. (2010). Knowledge sharing: A review and directions for future research. Human Resource Management Review, 20(2), 115-131.

Wasko, M.M., \& Faraj, S. (2005). Why should I share? Examining social capital and knowledge contribution in electronic networks of practice. MIS Quarterly, 29(1), 35-57. 
Wenger, E. (1998). Communities of Practice: Learning, Meaning, and Identity. Cambridge University Press.

Whitla, P. (2009). Crowdsourcing and its application in marketing activities. Contemporary Management Research, 5(1), 15-28.

Whittaker, S., Issacs, E., \& O'Day, V. (1997). Widening the net: Workshop report on the theory and practice of physical and network communities. SIGCHI Bulletin, 29(3), 27-30.

Wiertz, C., \& de Ruyter, K. (2007). Beyond the call of duty: Why consumers contribute to firm-hosted commercial online communities. Organization Studies, 28(3), 347-376.

Yang, J. (2007). The impact of knowledge sharing on organizational learning and effectiveness. Journal of Knowledge Management, 11(2), 83-90.

Yang, Q., Mudambi, R., \& Meyer, K.E. (2008). Convention and reverse knowledge flows in multinational corporations. Journal of Management, 34(5), 882-903.

Yoon, C., \& Rolland, E. (2012). Knowledge-sharing in virtual communities: Familiarity, anonymity and self-determination theory. Behavior \& Information Technology, 31(11), 1133-1143.

Zhao, Y., \& Zhu, Q. (2014). Evaluation on crowdsourcing research: Current status and future direction. Information Systems Frontiers, 16(3), 417434.

Zheng, H.L., \& Dahui, H.W. (2011). Task design, motivation, and participation in crowdsourcing contests. International Journal of Electronic Commerce, 115(4), 57-88.

\section{Abstract (in Polish)}

Jednym z stosunkowo nowych obszarów badań współczesnej nauki o zarzqdzaniu jest crowdsourcing oraz zachodzqce $w$ nim wirtualnym dzieleniu się wiedzq. Jest ono definiowane jako rozpowszechnienie wiedzy przez społeczność wirtualnq, informowanie innych, podawanie jej do wiadomości publicznej, oczekiwanie, że inni tę wiedzę skomentujq, rozszerzq i uzupełniq. Takie dzielenie się wiedzq jest szczególnie istotne dla współtworzenia, partycypacji czy uzyskiwania innowacyjnych pomysłów przez organizację. Jednak, pomimo jego pozytywnego wpływu na organizację, dotychczas nie było ono przedmiotem kompleksowych badań. Artykuł przedstawia istniejqcy dorobek w zakresie sposobów pomiaru społecznościowego dzielenia się wiedzq w ramach crowdsourcingu. W opracowaniu można też znaleźć wyjaśnienia, dlaczego warto badać wirtualne dzielenie się wiedzq.

Słowa kluczowe: wirtualne dzielenie się wiedzq; społeczność wirtualna; pomiar. 


\section{Biographical note}

Regina Lenart-Gansiniec, Assistant Professor at Jagiellonian University, Institute of Public Affairs. Expert in open innovation, knowledge management, clusters and public management of the Ministry of Economic Development (Poland) and Ministry of Economy (Poland). Research interests include open innovation, crowdsourcing, knowledge management, and organizational learning in public organizations. An author of publications on knowledge management, crowdsourcing, open innovation who has participated in several research projects. 
